\title{
Trwałość małżeństwa w świetle standardów międzynarodowych oraz orzecznictwa Europejskiego Trybunału Praw Człowieka
}

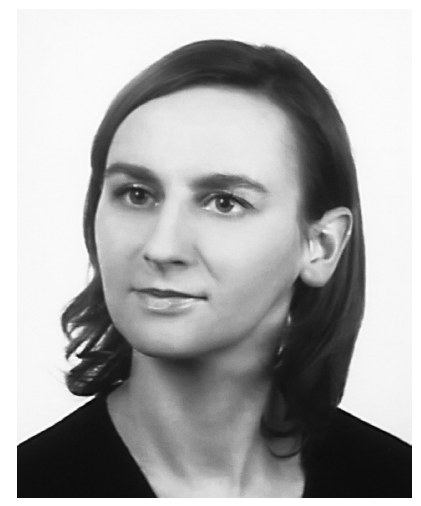

\section{Małgorzata Maria Łączkowska-Porawska}

Adiunkt w Poznańskim Centrum Prawa Rodzinnego i Praw Dziecka Instytutu Nauk Prawnych Polskiej Akademii Nauk, wykładowca na Uniwersytecie im. Adama Mickiewicza $w$ Poznaniu, specjalistka $w$ dziedzinie prawa rodzinnego i spadkowego.

$\triangle$ m.laczkowska-porawska@inp.pan.pl https://orcid.org/oooo-0002-0875-3598

\section{The Durability of Marriage in the Light of International Standards and Case Law of the European Court of Human Rights}

\begin{abstract}
The durability is not precisely mentioned as a features of marriage in international regulations but it results from the nature and purpose of this legal relationship. The analysis of the case law of the European Court of Human Rights in the context of the permanence of marriage lead to following conclusions. First, none of the provisions of the European Convention on Human Rights and Fundamental Freedoms, including Article 8 and 12, does not guarantee the right to divorce and this solution was precisely deliberated by the member states. Second, states have the power to regulate the provisions and the procedure concerning divorce in a manner that is appropriate to their cultural and ideological conditions, with respect of the principle of durability of marriage. The termination of marriage that depends on a permanent and complete breakdown of married life and on the consent of an innocent spouse does not, therefore, constitute a violation of the Convention. However, an unjustified extension of the divorce procedure resulting from circumstances attributable to the authorities were found to be inconsistent with the provisions of the Convention. In addition, the Article 12 of the Convention provides for the right to remarry for persons whose previous marriage was dissolved by divorce under national law. The article presents also recent propositions prepared by the European Commission of Family Law concerning liberalization of divorce law published in the Model Family Code.
\end{abstract}

Słowa kluczowe: trwałość małżeństwa, rozwód, prawo do rozwodu Key words: the durability of marriage, a divorce, the right to divorce https://doi.org/10.32082/fp.v2i52.221 
Dokonując analizy instytucji prawnej w kontekście standardów międzynarodowych, należy mieć na uwadze rangę i znaczenie tych regulacji dla krajowego systemu prawnego. Kwestię tę w polskiej rzeczywistości reguluje Konstytucja Rzeczypospolitej Polskiej ${ }^{1}$, przewidując, że najważniejszym źródłem prawa jest ustawa zasadnicza, a dopiero w dalszej kolejności ratyfikowane umowy międzynarodowe (art. 8 i art. 87 ust 1 . Konst.) $)^{2}$. Postanowienia konwencyjne nie mogą zatem naruszać polskiej ustawy zasadniczej i podlegają kontroli zgodności z jej treścią. Także interpretacja umów międzynarodowych przy dokonywaniu ich implementacji w porządku wewnętrznym wymaga uwzględnienia zasad i wartości konstytucyjnych.

Niniejsze opracowanie stanowi próbę spojrzenia na omawiane zagadnienie prawne, jakim jest trwałość małżeństwa, w nieco innym, bo ponadpaństwowym ujęciu ${ }^{3}$. Analiza treści adekwatnych postanowień umów międzynarodowych oraz wyroków Europejskiego Trybunału Praw Człowieka pozwala na wskazanie pewnej ogólnej idei oraz jej weryfikację w kontekście konkretnych uregulowań poszczególnych państw stron. Kluczowe w odniesieniu do spraw dotyczących regulacji prawa rodzinnego jest jednak co do zasady wyraźne uznanie w umowach międzynarodowych wyłącznych kompetencji legislacyjnych ustawodawcy krajowego w tym zakresie. Pamiętać także należy, że orzecznictwo Europejskiego Trybunału Praw Człowieka stanowi jedynie przykład interpretacji postanowień konwencyjnych, wywołujący skutki wyłącznie wobec państwa, w odniesieniu do którego sprawa była rozpatrywana.

1 Konstytucja Rzeczypospolitej Polskiej z dnia 2 kwietnia 1997 r. uchwalona przez Zgromadzenie Narodowe w dniu 2 kwietnia 1997 r., przyjęta przez Naród w referendum konstytucyjnym w dniu 25 maja 1997 r., podpisana przez Prezydenta Rzeczypospolitej Polskiej w dniu 16 lipca 1997 r., Dz.U. 1997 nr 78 poz. 483 ze zm.

2 Zasadę nadrzędności Konstytucji RP w kontekście uregulowań międzynarodowych wyraźnie podkreślił Trybunał Konstytucyjny w wyroku z dnia 11 maja 2005 r. Sygn. akt K $18 / 04$.

3 O zasadzie trwałości małżeństwa w kontekście prawa polskiego M. Łączkowska, Zasada trwałości małżeństwa w polskim prawie rodzinnym - aspekty materialne i procesowe, „Studia Prawnoustrojowe” 2014, nr 24, s. 61-81.
Trwałość związku małżeńskiego nie jest cechą wyraźnie wymienioną w standardach międzynarodowych dotyczących praw człowieka, dokumenty te bowiem wskazują przede wszystkim na istnienie prawa do zawarcia małżeństwa i założenia rodziny (art. 16 ust. 1 i $2 \mathrm{PDPC}^{4}$, art. 23 ust. 2 i $3 \mathrm{MPPOiP}^{5}$, art. 12 $\mathrm{EKPC}^{6}$ oraz art. $9 \mathrm{KPP}^{7}$ ). Ponieważ realizacja tego prawa pozostaje $\mathrm{w}$ ścisłym związku z uwarunkowaniami kulturowymi, obyczajowymi i religijnymi, kwestie związane z uregulowaniem zdolności do zawarcia małżeństwa, procedury oraz skutków małżeństwa pozostawiono ustawodawcy krajowemu. Podejmując działania legislacyjne w tym zakresie, zobowiązany jest on jednak do wskazania najniższego wieku uprawniającego do zawarcia małżeństwa, zagwarantowania dobrowolności zawierania związku małżeńskiego, rejestracji małżeństw oraz do zapewnienia równouprawnienia kobiet i mężczyzn w odniesieniu do praw i obowiązków wynikających ze statusu małżeńskiego (art. 16 PDPP, art. 5 Protokołu dodatkowego nr 7 do EKPC, art. $10 \mathrm{MPPGSiK}^{8}$, art. 1, 2 i 3 Konwencji w sprawie zgody na zawarcie małżeństwa, najniższego wieku małżeńskiego i rejestracji małżeństw $\left.{ }^{9}\right)$. Standardy międzynarodowe nakładają na państwo także obowiązek objęcia małżeństwa i rodziny szczególną ochroną (art. 10 MPPGSiK, art. 8 EKPC).

$\mathrm{Z}$ przywołanych regulacji o charakterze międzynarodowym wyinterpretować można, że małżeństwo to podlegający rejestracji, zawierany świadomie, dobrowolnie i w sposób sformalizowany związek

4 Powszechna Deklaracja Praw Człowieka (PDPC), http://libr. sejm.gov.pl/tek01/txt/onz/1948.html (dostęp 31.10.2018).

5 Międzynarodowy Pakt Praw Obywatelskich i Politycznych otwarty do podpisu w Nowym Jorku dnia 19 grudnia 1966 r. Dz.U. 1977 nr 38 poz. 167 (MPPOiP).

6 Konwencja o Ochronie Praw Człowieka i Podstawowych Wolności sporządzona w Rzymie dnia 4 listopada 1950 r., zmieniona następnie Protokołami nr 3, 5 i 8 oraz uzupełniona Protokołem nr 2., Dz.U. 1993 nr 61 poz. 284 (EKPC).

7 Karta Praw Podstawowych, Dz. Urz. UE 2012 C 326, s. 2 (KPP).

8 Międzynarodowy Pakt Praw Gospodarczych, Społecznych i Kulturalnych, Dz.U. 1977 nr 38 poz. 169 (MPPGSiK).

9 Konwencja w sprawie zgody na zawarcie małżeństwa, najniższego wieku małżeńskiego i rejestracji małżeństw, Dz.U. 1965 nr 9 poz. 53. 
kobiety i mężczyzny. Małżeństwo jest zatem związkiem dobrowolnym, sformalizowanym, heteroseksualnym i monogamicznym ${ }^{10}$. i wychowaniu potomstwa, czas jego trwania powinien obejmować przynajmniej realizację tego zadania. Celem tego związku jest także stworzenie w zasadzie

\section{Więzy rodzinne, a do takich należy małżeństwo,} mają trwałość wpisaną w swoją istotę.

Więzy rodzinne, a do takich należy małżeństwo mają trwałość wpisaną w swoją istotę.

Jak wspomniano, żaden z dokumentów międzynarodowych nie wskazuje natomiast wprost na trwałość jako cechę związku małżeńskiego. Uznać jednak należy, że wynika ona $\mathrm{z}$ charakteru oraz celu tego stosunku prawnego. Biorąc pod uwagę, że z założenia małżeństwo jest instytucją służącą zrodzeniu

10 Na temat heteroseksualności małżeństwa w świetle standardów międzynarodowych: A. Mączyński, Konstytucyjne i międzynarodowe uwarunkowania instytucjonalizacji związków homoseksualnych (w:) M. Andrzejewski (red.), Związki partnerskie debata na temat projektowanych zmian prawnych, Toruń 2013, s. 100; tenże, Zawarcie matżeństwa w prawie międzynarodowym (w:) W. Góralski (red.), Ius connubii ochrona i ograniczenia $w$ prawie międzynarodowym, polskim i kanonicznym, Płock 2016, s. 14; podobnie L. Garlicki (red.), Konwencja o ochronie praw człowieka i podstawowych wolności, t. 1: Komentarz do art. 1-18, Warszawa 2010, s. 712; L. Garlicki, M. Zubik (red.), Konstytucja Rzeczypospolitej Polskiej. Komentarz, t. 1, Warszawa 2016, s. 493; T. Jasudowicz, Prawo do zawarcia małżeństwa i założenia rodziny (w:) Prawa człowieka i ich ochrona, Toruń 2010, s. 429. O monogamicznym charakterze małżeństwa: K. Sękowska-Kozłowska, Międzynarodowy Pakt Praw Obywatelskich (Osobistych) i Politycznych. Komentarz, R. Wieruszewski (red.), Warszawa 2012, s. 582; L. Garlicki (w:) Konwencja..., dz. cyt., s. 712 i 717. Szerzej na temat obu wskazanych cech małżeństwa M. Łączkowska-Porawska, Heteroseksualność i monogamiczność małżeństwa jako stosunku prawnego, Warszawa 2019. Inaczej I.C. Kamiński, Karta Praw Podstawowych Unii Europejskiej. Komentarz, A. Wróbel (red.), 2013, s. 301, który podkreśla, że Karta Praw Podstawowych rezygnuje $\mathrm{z}$,powiązania małżeństwa i rodziny z monogamicznym związkiem o charakterze heteroseksualnym”. dozgonnej więzi między małżonkami obejmującej ich wspólne pożycie, opartej na wzajemnym udzielaniu sobie pomocy i wsparcia. Ponadto zawarcie małżeństwa prowadzi do powstania rodziny, która $\mathrm{z}$ istoty swojej ma trwały charakter, a wynikające z niej więzi wywołują skutki prawne nawet po śmierci jednego z jej członków (prawo spadkowe). Dopuszczalna przez krajowe systemy prawne możliwość rozwiązania stosunku rodzinnoprawnego należy do sytuacji wyjątkowych i dotyczy jedynie małżeństwa i niektórych rodzajów przysposobienia.

Należy także podkreślić, że pomoc i ochrona udzielana przez państwo naturalnej i podstawowej grupie społecznej, jaką jest rodzina, znajduje uzasadnienie w przyjęciu przez jej członków trwałych obowiązków względem siebie nawzajem (art. 10 MPPGSiK).

Inwestycja państwa w małżeństwo i rodzinę ma stanowić wsparcie dla realizowania przez nie funkcji niezbędnych do budowania społeczeństwa.

Małżonkowie mogą korzystać z określonych przez prawo przywilejów właśnie dlatego, że przyjęli na siebie wzajemne zobowiązania ograniczające w istotnym zakresie ich indywidualną wolność (obowiązek wierności, obowiązek udzielania pomocy, obowiązek ponoszenia kosztów utrzymania rodziny, objęcie praw nabywanych w trakcie trwania małżeństwa wspólnością majątkową).

W momencie powstawania dokumentów regulujących prawa człowieka trwałość związku małżeńskiego uzasadniona w przedstawiony powyżej sposób nie budziła wątpliwości. Rozwód traktowany był przez systemy prawne jako ostateczność, a jego uzyskanie było obwarowane restrykcyjnymi przesłankami wskazanymi w ustawie. Do połowy XX w. prawo rozwodowe służyć miało zagwarantowaniu trwałości małżeństwa, 
a rozwiązanie tej relacji prawnej traktowane było jako sankcja dla małżonka, który naruszył swoje obowiązki małżeńskie, stąd istotne znaczenie $\mathrm{w}$ ramach procedury rozwodowej miało ustalenie winy, która z kolei miała wpływ zarówno na samo rozwiązanie małżeństwa, jak i na sytuację majątkową małżonków po ustaniu ich związku. W latach 70. XX w. rozpoczął się proces „prywatyzacji” małżeństwa, poprzez koncentrację na rzeczywistej relacji między małżonkami oraz przyznanie priorytetu autonomii woli stron, a wycofanie się państwa. Stąd zaczęto odchodzić od koncepcji wynika jednak, aby w ramach praw człowieka można było wyróżnić prawo do rozwodu. W opracowaniach naukowych zwraca się natomiast uwagę, że całkowity zakaz rozwodu narusza prawo do prywatności i prawo do zawarcia małżeństwa. Jako potwierdzenie tej tezy przywołuje się art. 23 ust. 4 MPPOiP, który wskazuje na możliwość rozwiązania małżeństwa ${ }^{12}$. Na tę samą podstawę prawną powołał się także Komitet Praw Człowieka, stwierdzając, że „brak instytucji rozwodu w chilijskim prawie może stanowić naruszenie art. 23 ust. 2 Paktu, zgodnie z którym mężczyźni

\section{Inwestycja państwa w małżeństwo i rodzinę} ma stanowić wsparcie dla realizowania przez nie funkcji niezbędnych do budowania społeczeństwa.

winy przy rozwodzie, upraszczać procedurę w przypadku, gdy oboje małżonkowie godzą się na rozwód, wprowadzono także mediację jako sposób osiągnięcia kompromisu w „pokojowym rozejściu się"11.

Wśród praw przysługujących człowiekowi nie ma prawa do rozwodu, a przewidziane przez prawo krajowe przesłanki rozwiązania małżeństwa nie naruszają art. 12 EKPC.

Zasada trwałości małżeństwa znajduje zatem swój wyraz przede wszystkim w sposobie uregulowania możliwości rozwiązania małżeństwa na żądanie jednego lub obojga małżonków. Przyjęcie stosownych przepisów w tym zakresie znajduje się w gestii państw członkowskich, poza kompetencjami organizacji międzynarodowych. Akty międzynarodowych praw człowieka wspominają o rozwodzie, wskazując jedynie, iż w zakresie dostępu do tej instytucji oraz jej skutków musi obowiązywać zasada równego traktowania kobiet i mężczyzn (art. 23 ust. 4 zd. 1 MPPPiO). Wymaga się ponadto odpowiedniego zabezpieczenia interesu dzieci pochodzących z rozwodzącego się małżeństwa (art. 23 ust. 4 zd. 2 MPPPiO). Z przywołanych regulacji nie

11 I. Schwenzer, M. Dimsey, Model Family Code from a global perspective, Antwerpia-Oxford 2006, s. 2. i kobiety, którzy osiągnęli wiek małżeński, mają prawo do zawarcia małżeństwa i założenia rodziny"13. Taka interpretacja przywołanego przepisu budzi jednak poważne wątpliwości. Osoba pozostająca w związku małżeńskim, który chciałaby rozwiązać, zrealizowała już swoje prawo do zawarcia małżeństwa i założenia rodziny. Regulacja ta nie gwarantuje natomiast prawa do zgodnego z wolą jednego lub obojga małżonków ustania małżeństwa i do ponownego zawarcia takiego związku z inną osobą. Rozwód nie jest zatem instytucją realizującą prawo podmiotowe do nowego małżeństwa, stanowi bowiem rozwiązanie prawne, które umożliwia ustanie małżeństwa de facto już niefunkcjonującego.

Za zaskakujące uznać należy także wskazanie przez Komitet Praw Ekonomicznych, Socjalnych i Kultural-

12 M. Nowak, U.N. Convenant on Civil and Political Rights. CCPR Commentary, Kehl-Strassburg-Arlington 2005, s. 530-531. Cyt. za K. Sękowska-Kozłowska, Międzynarodowy Pakt Praw..., dz. cyt., s. 585-586.

13 Uwagi końcowe z 1999 r. do sprawozdania Chile, CCPR/A/ $54 / 40$, pkt 213. Kilka lat później Komitet z aprobatą przyjął dokonaną w chilijskim prawie zmianę wprowadzającą rozwód. Uwagi końcowe z 2007 r. do sprawozdania Chile, CCPR/C/ $\mathrm{CHL} / \mathrm{CO} / 5$, pkt 3 . 
nych art. 10 MPPGSiK jako źródła obowiązku wprowadzenia do prawa krajowego instytucji rozwodu ${ }^{14}$. Regulacja ta bowiem stanowi w gruncie rzeczy uzasadnienie dla trwałości małżeństwa, nakładając na państwa obowiązek udzielania jak najszerszej ochrony i pomocy rodzinie jako naturalnej i podstawowej komórce społeczeństwa, w szczególności przy jej zakładaniu i w okresie trwania odpowiedzialności za opiekę i wychowanie dzieci pozostających na jej utrzymaniu.

Kwestie dopuszczalności rozwodu oraz jego prawnych konsekwencji były kilkukrotnie rozpatrywane przez Europejski Trybunał Praw Człowieka.

W sprawie Johnston przeciwko Irlandii ${ }^{15}$ skarżący zarzucał, iż brak możliwości uzyskania rozwodu w prawie irlandzkim stanowi naruszenie art. 12 EKPC, ponieważ uniemożliwia tym samym zawarcie nowego i podstawowych wolności, w których podkreślono, że wzorując się na art. 16 PDPC, zdecydowano się jedynie na fragmentaryczne wykorzystanie jego treści, zaliczając tym samym do katalogu praw człowieka jedynie prawo do zawarcia małżeństwa i założenia rodziny ${ }^{16}$.

Europejski Trybunał Praw Człowieka rozpatrywał także skargę F. przeciwko Szwajcarii ${ }^{17}$, w której skarżący po trzech rozwodach powoływał się na niezgodność $\mathrm{z}$ art. 12 EKPC art. 150 szwajcarskiego kodeksu cywilnego, na podstawie którego sąd orzekający rozwód powinien określić pewien okres, nie krótszy niż rok, nie dłuższy niż dwa lata od orzeczenia rozwodu, w którym małżonek uznany za winnego rozkładu pożycia nie będzie mógł wstąpić w nowy związek małżeński. W wyroku, osiągniętym większością dziewięć do ośmiu, Trybunał stwierdził, że wprowadze-

\section{Wśród praw przysługujących człowiekowi} nie ma prawa do rozwodu, a przewidziane przez prawo krajowe przesłanki rozwiązania małżeństwa nie naruszają art. 12 EKPC.

związku małżeńskiego. Trybunał stwierdził jednak, że ani art. 8, ani art. 12 EKPC nie gwarantują prawa do rozwodu. Oceniając przedstawioną sytuację, podkreślił, że mimo występującego w praktyce wzrostu liczby rozwodów w Europie oraz przy uwzględnieniu konieczności dokonywania wykładni konwencji i jej protokołów w odniesieniu do aktualnej rzeczywistości, nie można, stosując interpretację ewolucyjną, wyprowadzić prawa, które nie było od samego początku zawarte w stosowanych regulacjach. W tej kwestii Trybunał odwołał się do travaux preparatoires do Europejskiej konwencji o ochronie praw człowieka

14 Zalecenia Komitetu Praw Ekonomicznych, Socjalnych i Kulturalnych z 1 grudnia 2008 r. do sprawozdania Filipin E/C.12/ $\mathrm{PHL} / \mathrm{CO} / 4$

15 Wyrok ETPC z 18 grudnia 1986 r., skarga nr 9697/82 (dostęp na www.echr.coe.int). nie czasowego ograniczenia możliwości zawarcia kolejnego małżeństwa po rozwodzie narusza prawo gwarantowane w art. 12 EKPC. Zdaniem Trybunału, jeżeli prawo danego państwa przewiduje możliwość rozwodu, to art. 12 EKPC chroni prawo rozwiedzionego małżonka do zawarcia nowego małżeństwa bez nieuzasadnionych restrykcji. Warto zwrócić jednak uwagę na zdanie odrębne zgłoszone do tego wyroku przez kilku sędziów ${ }^{18}$. Nie zgodzili się oni z werdyktem większości, uznając, że w sprawie nie wykazano, aby zakaz zawarcia związku małżeńskiego na okres

16 Collected Edition of the Travaux préparatoires, vol. 1, p. 268.

17 Wyrok ETPC z 18 grudnia 1987 r., nr skargi 11329/85 (dostęp na www.echr.coe.int)

18 Sędziowe ci to: T. Vilhjàlmsson, D. Bindschedler-Robert, F. Gölcüklü, F. Matscher, J. Pinheiro Farinha, B. Walsh, J. De Meyer i N. Valcitos (8 z 17 orzekających). 
trzech lat naruszał istotę prawa do zawarcia małżeństwa i założenia rodziny przewidzianego $\mathrm{w}$ art. 12 EKPC. Po pierwsze, podkreślili, że zakaz ten miał charakter czasowy. Po drugie, przewidziane w prawie szwajcarskim ograniczenie służyć miało nie tylko ochronie instytucji małżeństwa, ale także przyszłego małżonka osoby, która dotychczas w poważnym stopniu naruszyła podstawowe prawa i obowiązki małżeńskie. Ingerencja ustawodawcy w prawa przysługujące na podstawie art. 12 EKPC miała zatem ich zdaniem wystarczające uzasadnienie.

W dwóch kolejnych sprawach Trybunał orzekał w kwestii wpływu długości postępowania rozwodowego na prawo do zawarcia małżeństwa i założenia rodziny (art. 12 EKPC). W wyroku w sprawie Aresti Charalambous przeciwko Cyprowi ${ }^{19}$ nie wykluczył, że przewlekłość postępowania w niektórych okolicznościach może naruszać art. 12 EKPC, stwierdził jednak, że w przywołanej sprawie takowe nie występują, gdyż opóźnienia wynikały z okoliczności występujących po stronie małżonków (odraczanie postępowania oraz kwestie związane z prawem imigracyjnym). Natomiast w sprawie V. K. przeciwko Chorwacji ${ }^{20}$ za takie okoliczności uznał zaniedbania ze strony organów publicznych związane z postępowaniem rozwodowym, mimo gwarantowanej przez prawo konieczności traktowania spraw rodzinnych jako szczególnie pilnych (art. 263 chorwackiego kodeksu rodzinnego) oraz możliwości częściowego rozpatrywania sprawy (art. 329 chorwackiego kodeksu postępowania cywilnego). Osoba występująca z powództwem rozwodowym w celu zawarcia nowego małżeństwa, pozostająca w przedłużającym się stanie niepewności, doświadczyła, zdaniem Trybunału, w tym konkretnym stanie faktycznym, niczym nieuzasadnionego ograniczenia prawa do zawarcia związku małżeńskiego. Za trafną należy jednak uznać uwagę wyrażoną w zdaniu odrębnym do omawianego wyroku. Podkreślono w nim, że nie sama długość procedury rozwodowej narusza art. 12 EKPC, lecz wystąpienie szczególnych okoliczności związanych z trwaniem

19 Wyrok ETPC z 19 lipca 2007 r., skarga nr 43151/04 (dostęp na www.echr.coe.int).

20 Wyrok ETPC z 27 listopada 2012 r., skarga nr 38380/08 (dostęp na www.echr.coe.int). postępowania, które mogą prowadzić do naruszenia istoty prawa do zawarcia małżeństwa. Wskazując, że ochrona przed przewlekłością postępowań sądowych wynika $\mathrm{z}$ art. 6 EKPC, uznano, że w omawianej sprawie nie wykazano, aby fakt upływu czasu, w którym trwało postępowanie rozwodowe, naruszył istotę prawa do zawarcia małżeństwa. Doprowadził on natomiast z pewnością do opóźnienia możliwości skorzystania z tego prawa, co nie stanowiło jednak naruszenia art. 12 EKPC.

Następne orzeczenie Europejskiego Trybunału Praw Człowieka dotyczące rozwodu zapadło w sprawie Ivanov i Petrova przeciwko Bułgarii ${ }^{21}$. W tym przypadku mąż zaskarżył wyrok, w którym odmówiono mu rozwodu ze względu na brak przekonania sądu o trwałym i zupełnym rozkładzie pożycia. Sąd uznał bowiem, że przywoływane przez powoda M. Ivanova okoliczności związane z brakiem kompromisu dotyczącego miejsca wspólnego zamieszkiwania małżonków i wynikająca stąd separacja nie stanowią problemu, który nie mógłby zostać między małżonkami rozwiązany, zwłaszcza że żona powoda chciałaby pogodzić się z mężem, a ich wspólne małoletnie dzieci potrzebują obecności ojca. Ważnych powodów uzasadniających rozwód nie stanowi także niewywołujący konfliktów między małżonkami fakt, że mąż ma dziecko $\mathrm{z}$ inną kobietą, nie deklaruje jednak chęci związania się z matką dziecka pozamałżeńskiego. M. Ivanov powołał się w swojej skardze na naruszenie jego prawa do ochrony życia rodzinnego i prywatnego (art. 8 EKPC) oraz prawa przysługującego jemu i jego nowej partnerce do zawarcia związku małżeńskiego (art. 12 EKPC). Europejski Trybunał Praw Człowieka uznał, że skarga w opisanej sprawie dotyczy nie braku możliwości rozwiązania małżeństwa przez rozwód w prawie bułgarskim, lecz odrzucenia przez sąd bułgarski powództwa rozwodowego w konkretnym przypadku. Nawiązując do sprawy Johnston i inni przeciwko Irlandii, podkreślił, że skoro art. 8 i 12 EKPC nie stanowi podstawy dla istnienia prawa do rozwodu, to nie może uzasadniać oczekiwania rozpatrzenia sprawy rozwodowej w określony sposób, realizujący potrzeby powoda.

21 Wyrok ETPC z 14 czerwca 2011 r., skarga nr 15001/04 (dostęp na www.echr.coe.int). 
W odniesieniu do skargi H. Petrovej powołującej się na naruszenie jej prawa do zawarcia małżeństwa z M. Ivanovem Trybunał podkreślił, że niemożność zawarcia związku z osobą, która nie uzyskała rozwodu, realizuje zasadę monogamii powszechnie obowiązującą we wszystkich państwach należących do Rady Europy. Regulacja taka nie stanowi zatem naruszenia art. 12 EKPC.

Kontynuację dotychczasowego orzecznictwa Europejskiego Trybunału Praw Człowieka stanowi wyrok w sprawie Babiarz przeciwko Polsce ${ }^{22}$. Skarżący podnosił, że przewidziany w polskim prawie obowiązek odmowy orzeczenia rozwodu w sytuacji, gdy z żądaniem występuje małżonek wyłącznie winny rozkładu wspólnego pożycia, a drugi małżonek nie wyraża zgody na rozwód, przy czym brak tej zgody nie jest sprzeczny z zasadami współżycia społecznego, sta- w celu zapewnienia zgodności z Konwencją i pogodzenia wchodzących w grę konkurencyjnych interesów osobistych". Ze względu na powyższe nie stwierdził naruszenia art. 12 EKPC, podkreślając, że art. 56 $\$ 3$ k.r.o. „może być uważany za gwarancję mającą na celu ochronę jednej ze stron, zazwyczaj słabszej wobec machinacji i złej woli drugiej strony". Trybunał zaznaczył, że „przyjęcie innego poglądu oznaczałoby, że pozew rozwodowy musiałby być uznany niezależnie od proceduralnych i materialnych przepisów krajowego prawa rozwodowego w sytuacji, w której dana osoba po prostu zdecydowałaby się opuścić swojego małżonka i posiadać dziecko z nowym partnerem. Choć zgodnie $\mathrm{z}$ art. 8 de facto rodziny i związki międzyludzkie są chronione, taka ochrona nie oznacza, że należy w szczególny sposób dokonać uznania prawnego [nowego związku]".

\section{Wypełnianie roli małżonka zawsze $w$ większym lub} mniejszym stopniu wiąże się $\mathrm{z}$ rezygnacją z pewnej sfery własnej wolności osobistej, jest to jednak wynikiem samodzielnie podjętej decyzji o zawarciu związku małżeńskiego z konkretną osobą.

nowi naruszenie art. 8 i 12 EKPC. Uzasadniając swoją skargę, powoływał się na to, że odmowa rozwiązania małżeństwa ze względu na brak zgody jego żony na rozwód stanowi naruszenie jego prawa do zawarcia małżeństwa i założenia rodziny oraz ingerencję w życie prywatne i rodzinne jego, jego partnerki oraz ich wspólnego dziecka.

Rozpatrując tę sprawę, Trybunał stwierdził, że „w obszarze kształtowania swego prawa rozwodowego i wdrażania go w konkretnych przypadkach Układające się Strony mają do dyspozycji szeroki margines oceny w określaniu kroków, jakie należy podjąć

22 Wyrok ETPC z 10 stycznia 2017 r., skarga nr 1955/10 (dostęp na www.echr.coe.int).
Postanowienie konwencji próbuje się jednak współcześnie interpretować w inny sposób. Ciekawym źródłem informacji na ten temat mogą być zdania odrębne zgłoszone przez sędziów do wyroku w sprawie Babiarz przeciwko Polsce. W obu dołączonych do wskazanego orzeczenia opiniach negatywnie oceniono fakt kontynuacji interpretacji art. 12 EKPC dokonanej w 1987 r., zgodnie z którą nie przewiduje on prawa do rozwodu. Wręcz przeciwnie, zasugerowano, że artykuł ten przewiduje prawo do rozwodu jako wstępny warunek wykonywania prawa do ponownego małżeństwa ${ }^{23}$.

Sędziowie dystansujący się wobec decyzji większości zwrócili uwagę na potrzebę traktowania konwencji

23 Opinia odrębna sędziego P. Dealbuquerque. 
jako żywego instrumentu, którego wykładnia powinna ewoluować, uwzględniając „czynnik rosnącego europejskiego konsensu w sprawie prawa rozwodowego"24. W dalszej części autorzy zdań odrębnych wskazują na istotne przemiany w społecznym rozumieniu istoty małżeństwa. Nie godząc się z treścią wyroku, podkreślili, że prawo do ochrony życia rodzinnego nie obejmuje prawa do życia rodzinnego z konkretną osobą wbrew jej woli. Prawo do ochrony życia prywatnego, zdaniem sędziów będących w mniejszości, gwarantuje natomiast brak przymusu życia w małżeństwie $\mathrm{z}$ inną osobą jako wyraz prawa do samodzielnego „takiej woli nie ma już u jednej ze stron, niewiele już łączy związek małżeński” ${ }^{\text {"26 }}$. Małżeństwo jest bowiem stosunkiem prawnym, z którego wynikają pewne obowiązki wobec współmałżonka, takie jak budowanie wspólnego pożycia, wzajemna pomoc, wierność i lojalność. Łączy się z nimi prawo drugiej strony do oczekiwania ich realizacji.

Wypełnianie roli małżonka zawsze w większym lub mniejszym stopniu wiąże się z rezygnacją z pewnej sfery własnej wolności osobistej, jest to jednak wynikiem samodzielnie podjętej decyzji o zawarciu związku małżeńskiego z konkretną osobą.

\section{Utrzymywanie więzi małżeńskiej i uzależnienie} rozwiązania tego związku od decyzji sądu stanowi realizację obowiązku wynikającego ze standardów międzynarodowych, a polegającego na ochronie małzeństwa i rodziny.

decydowania o swojej sytuacji rodzinnej. Powołali się oni także na fakt, że małżeństwo jest związkiem dobrowolnym ${ }^{25}$.

Wszystkie te argumenty są po części prawdziwe. Rzeczywiście, nie można nikogo zmusić do zawarcia związku małżeńskiego wbrew jego woli, i regulacje międzynarodowe dają temu wyraz, gwarantując prawo do zawarcia małżeństwa i założenia rodziny z zastrzeżeniem świadomej i dobrowolnej zgody obu stron przy zawieraniu tego związku. Przewidują także ochronę istniejącego, a nie potencjalnego życia rodzinnego. Nie można natomiast zaakceptować koncepcji o dobrowolności pozostawania w już zawartym związku małżeńskim, zgodnie z którą „dobrowolne zjednoczenie istnieje wtedy, gdy obie strony wyrażają jedną wolę [pozostawania w małżeństwie]”, a gdy

24 Opinia odrębna sędziego P. Dealbuquerque, podobnie w swojej opinii odrębnej sędzia A. Sajó.

25 Opinia odrębna sędziego A. Sajó.
Nie do zaakceptowania jest zatem twierdzenie, że „dążenie do tego, by zatrzymać kogoś jako współmałżonka, nie jest równie istotne jak oparte na autonomii pragnienie drugiej osoby do wolności, a nadto jest asymetryczne, ponieważ nakłada nadmierne ograniczenia, podczas gdy opuszczenie jest prawem przyznanym obu stronom jednakowo"27. Prawna konstrukcja małżeństwa nie zawiera bowiem w sobie "prawa do opuszczenia" współmałżonka, wręcz przeciwnie zachowanie takie traktowane jest jako naruszenie obowiązków. Sprzeczna z prawną wizją małżeństwa jest w związku z tym koncepcja, zgodnie z którą jedna ze stron ma prawo podjąć „prywatną i rodzinną decyzję o zaprzestaniu kontynuowania życia w ramach takiej więzi prawnej", a państwo nie powinno mieć możliwości utrwalania tej więzi wbrew woli tego małżonka ${ }^{28}$.

\footnotetext{
26 Opinia odrębna sędziego A. Sajó.

27 Opinia odrębna sędziego A. Sajó.

28 Opinia odrębna sędziego A. Sajó.
} 
Utrzymywanie więzi małżeńskiej i uzależnienie rozwiązania tego związku od decyzji sądu stanowi bowiem realizację obowiązku wynikającego ze standardów międzynarodowych polegającego na ochronie małżeństwa i rodziny.

Ochrona ta obejmuje nie tylko interesy małżonka, który występuje o rozwiązanie jego małżeństwa, ale także interesy drugiego małżonka oraz ich wspólnych dzieci. Stąd nie można przyjąć, iż ważniejsze od prawa trwałości, ponieważ w takim związku, „jeżeli przynajmniej jedna osoba postrzega ową wymianę jako niekorzystną dla siebie, nic nie powstrzymuje jej przed


małżeństwa jako szczególnej instytucji o wymiarze społecznym, traktując małżeństwo raczej jako kontrakt pomiędzy małżonkami regulujący ich wzajemną relację na bliżej nieokreślony, zależny od ich aktualnej woli, czas.

\section{Prywatyzacja małżeństwa i odejście od przywiązania do trwałości i społecznych funkcji tego związku stawiają pod znakiem zapytania sensowność wyróżnienia tego stosunku społecznego.}

małżonka niewinnego do utrzymania więzi małżeńskiej jest „prawo do uwolnienia się z tej więzi w celu założenia nowej legalnej rodziny" ${ }^{29}$.

Przedstawione w obu opiniach argumenty podważające prawidłowość wyroku w sprawie Babiarz przeciwko Polsce odpowiadają ponowoczesnej, indywidualistycznej koncepcji małżeństwa, która służyć ma przede wszystkim zaspokajaniu potrzeb jednostki i jej samorealizacji ${ }^{30}$. Małżeństwo indywidualistyczne oparte na tzw. czystej relacji ${ }^{31}$ trudno pogodzić z zasadą

29 Opinia odrębna sędziego P. Dealbuquerque.

$30 \mathrm{Na}$ ten temat: P.R. Amato, Institutional, companionate and individualistic marriages. Change over time and implications for marital quality (w:) M. Garrison, E.S. Scott (red.), Marriage at the crossroads. Law, policy and the brave new world of twenty-first-century families, Cambridge 2012, s. 109; K. Slany, Alternatywne formy życia matżeńsko-rodzinnego w ponowoczesnym świecie, Kraków 2002, s. 14; J. Jones, E. Merino-Blanco, The influence of constitutional law on family forms in Germany and Spain, „20 Child \& Family Law Quarterly” 2008 , t. 23, s. 42.

31 Pojęciem „czystej relacji” posługuje się A. Giddens, definiując ją jako relację społeczną, „która jest samowystarczalna, to znaczy zasadniczo oparta na satysfakcji i gratyfikacji, których sama dostarcza”. A. Giddens, Nowoczesność a tożsamość.
Idąca w tym kierunku prywatyzacja małżeństwa i odejście od przywiązania do trwałości i społecznych funkcji tego związku stawiają jednak pod znakiem zapytania sensowność wyróżnienia tego stosunku społecznego.

Zauważyć należy, że przewidziane w standardach międzynarodowych regulacje dotyczące małżeństwa i rodziny opierają się jednak na założeniu, że konieczność ochrony tych instytucji wiąże się z pokładanymi w nich nadziejami państwa i społeczeństwa.

Z przywołanego w niniejszym opracowaniu orzecznictwa Europejskiego Trybunału Praw Człowieka w kontekście trwałości małżeństwa można zatem wyciągnąć następujące wnioski. Po pierwsze, żadne z postanowień konwencji, w tym także art. 8 i 12, nie gwarantuje prawa do rozwodu, co stanowiło celowy

"Ja” i społeczeństwo w epoce późnej nowoczesności, Warszawa 2001, s. 314, więcej na temat czystej relacji na s. 122 i n.; tenże, Przemiany intymności. Seksualność, miłość, erotyzm we współczesnych społeczeństwach, Warszawa 2006, s. 81.

32 D. Majka-Rostek, Związki jednoptciowe jako „czysta relacja” (w:) K. Slany, B. Kowalska, M. Ślusarczyk (red.), Kalejdoskop genderowy. W drodze do poznania płci społeczno-kulturowej w Polsce, Kraków 2011, s. 507. 
zabieg twórców regulacji. Po drugie, państwa mają kompetencję do regulacji przesłanek i procedury rozwodowej w sposób odpowiadający ich uwarunkowaniom kulturowym i światopoglądowym, z poszanowaniem zasady trwałości małżeństwa. Uzależnienie możliwości rozwiązania małżeństwa od wystąpienia trwałego i zupełnego rozkładu pożycia oraz od zgody małżonka niewinnego zaistniałej między małżonkami sytuacji nie stanowi w związku z tym naruszenia konwencji. Za niezgodne z postanowieniami konwencyjnymi uznano natomiast ograniczenie możliwości zawarcia związku małżeńskiego osobie rozwiedzionej oraz nieuzasadnione przedłużenie procedury rozwodowej wynikające z okoliczności zawinionych przez organy orzekające. Zgodnie z art. 12 EKPC istnieje bowiem prawo do ponownego małżeństwa dla osób, których poprzednie małżeństwo zostało rozwiązane przez rozwód przewidziany w prawie krajowym. Pojawia się ono jednak dopiero po ustaniu wcześniejszego związku.

Analizując kwestię trwałości małżeństwa w świetle standardów międzynarodowych, warto zwrócić uwagę nie tylko na wiążące zobowiązania konwencyjne, ale także na zgłaszane w dyskursie naukowym na forum międzynarodowym sugestie optymalnych rozwiązań prawnych ${ }^{33}$. Za interesującą w tym kontekście uznać należy propozycję modelowego kodeksu rodzinnego, której autorzy podkreślają, że zaproponowana przez nich wizja rozwodu odpowiada nowoczesnemu podejściu do małżeństwa stawiającemu na pierwszym miejscu aktualną wolę małżonków ponad ochroną małżeństwa jako instytucji. Ich zdaniem podstawowym celem prawa rozwodowego powinno być bowiem odpowiednie uregulowanie konsekwencji ustania małżeństwa służące ochronie strony słabszej ${ }^{34}$. Dlatego jedyną przesłankę gwa-

33 Szczególną rolę w tej kwestii odgrywa działalność Komisji Europejskiego Prawa Rodzinnego (CEFL), która stanowi platformę współpracy naukowców - specjalistów prawa rodzinnego reprezentujących różne państwa europejskie. Więcej na temat samej Komisji, sposobu jej procedowania oraz znaczenia przygotowywanych opracowań A. Wysocka-Bar, Prawo rozwodowe w pracach Komisji Europejskiej Prawa Rodzinnego (CEFL), „Kwartalnik Prawa Prywatnego” 2018, nr 2 .

34 I. Schwenzer, M. Dimsey, Model family code..., dz. cyt., s. 22. rantującą rozwód powinna stanowić wola obojga małżonków lub jednego z nich wyrażona w powództwie wniesionym do sądu. Sąd w takiej sytuacji nie posiadałby kompetencji do ustalania, czy i z jakich powodów doszło do rozpadu małżeństwa. Autorzy modelowego kodeksu rodzinnego przyjmują bowiem za zasadę niezależne prawo każdego z małżonków do uzyskania rozwodu bez względu na jakiekolwiek dodatkowe okoliczności ${ }^{35}$.

Zauważyć można istotną sprzeczność sugerowanych rozwiązań z ideami zawartymi w standardach międzynarodowych, wśród których mieści się także zasada ochrony rodziny właśnie jako instytucji. Autorzy modelowego kodeksu rodzinnego wychodzą bowiem z założenia, że celem nowoczesnego prawa dotyczącego rozwiązania małżeństwa nie jest już ochrona tej szczególnej instytucji społecznej, lecz ochrona słabszej strony postępowania rozwodowego. Przedmiotu regulacji prawnej nie ma zatem ich zdaniem stanowić odpowiedź na pytanie, kiedy można rozwiązać małżeństwo, a sąd nie ma orzekać o tym, czy w danych okolicznościach rozwód jest dopuszczalny. Nowoczesne prawo powinno traktować rozwód jako oczywistą realizację uprawnienia przysługującego każdemu z małżonków stojącego ponad interesem innych osób. Zadaniem ustawodawcy miałoby być natomiast jedynie wprowadzenie takich rozwiązań na wypadek ustania małżeństwa, które chroniłyby sytuację strony słabszej. Zauważyć należy, że taka wizja rozwodu realizowana jest coraz częściej w ustawodawstwach państw europejskich, nie oznacza to jednak, że stanowi ona obowiązkowy wzorzec uzasadniony nałożonymi na państwa zobowiązaniami międzynarodowymi.

Na zakończenie raz jeszcze należy podkreślić, że trwałość małżeństwa w świetle standardów międzynarodowych stanowi cechę tego stosunku prawnego wynikającą z jego funkcji społecznych. Kwestie dotyczące dopuszczalności rozwodu, jego przesłanek materialnych, przebiegu procedury, a także skutków rozwiązania małżeństwa stanowią sferę podlegającą wyłącznej kompetencji ustawodawcy krajowego.

35 Tamże, s. 23. 


\section{Bibliografia}

Amato P.R., Institutional, companionate and individualistic marriages. Change over time and implications for marital quality (w:) M. Garrison, E.S. Scott (red.), Marriage at the crossroads. Law, policy and the brave new world of twenty-first-century families, Cambridge 2012.

Garlicki L. (red.), Konwencja o ochronie praw człowieka i podstawowych wolności, t. 1: Komentarz do art. 1-18, Warszawa 2010.

Garlicki L., Zubik M. (red.), Konstytucja Rzeczypospolitej Polskiej, Komentarz, t. 1, Warszawa 2016.

Giddens A., Nowoczesność a tożsamość. „Ja” i społeczeństwo w epoce późnej nowoczesności, Warszawa 2001.

Giddens A., Przemiany intymności. Seksualność, miłość, erotyzm we wspótczesnych społeczeństwach, Warszawa 2006.

Jasudowicz T., Prawo do zawarcia małżeństwa i założenia rodziny (w:) Prawa człowieka i ich ochrona, Toruń 2010.

Jones J., Merino-Blanco E., The influence of constitutional law on family forms in Germany and Spain, „20 Child \& Family Law Quarterly" 2008, t. 23.

Łączkowska M., Zasada trwałości małżeństwa w polskim prawie rodzinnym - aspekty materialne i procesowe, „Studia Prawnoustrojowe" 2014, nr 24.

Łączkowska-Porawska M., Heteroseksualność i monogamiczność małżeństwa jako stosunku prawnego, Warszawa 2019.
Majka-Rostek D., Związki jednoptciowe jako „czysta relacja” (w:) K. Slany, B. Kowalska, M. Ślusarczyk (red.), Kalejdoskop genderowy. W drodze do poznania płci społeczno-kulturowej $w$ Polsce, Kraków 2011.

Mączyński A., Konstytucyjne i międzynarodowe uwarunkowania instytucjonalizacji związków homoseksualnych (w:) M. Andrzejewski (red.), Związki partnerskie debata na temat projektowanych zmian prawnych, Toruń 2013.

Mączyński A., Zawarcie małżeństwa w prawie międzynarodowym (w:) W. Góralski (red.), Ius connubii ochrona i ograniczenia w prawie międzynarodowym, polskim i kanonicznym, Płock 2016.

Schwenzer I., Dimsey M., Model Family Code from a global perspective, Antwerpia-Oxford 2006.

Slany K., Alternatywne formy życia małżeńsko-rodzinnego w ponowoczesnym świecie, Kraków 2002.

Wieruszewski R. (red.), Międzynarodowy Pakt Praw Obywatelskich (Osobistych) i Politycznych. Komentarz, Warszawa 2012.

Wróbel A. (red.), Karta Praw Podstawowych Unii Europejskiej. Komentarz, Warszawa 2013.

Wysocka-Bar A., Prawo rozwodowe w pracach Komisji Europejskiej Prawa Rodzinnego (CEFL), „Kwartalnik Prawa Prywatnego" 2018, nr 2. 